\title{
Determination of Heavy Metals in Water, Fish and Sediment from Ureje Water Reservoir
}

\author{
Adebayo IA* \\ Faculty of Agricultural Sciences, Ekiti State University, Ado Ekiti, Ekiti State, Nigeria
}

\begin{abstract}
The concentrations of Iron (Fe), Copper (Cu), Zinc ( $\mathrm{Zn})$, Lead (Pb), Cadmium (Cd), Chromium ( $\mathrm{Cr}$ ) and Manganese $(\mathrm{Mn})$ in water, sediment and selected fish samples from Ureje water reservoir, Ado Ekiti, were determined using Atomic Absorption Spectrophotometer (AAS). A total of three samples each of water, sediment, fishes (Hemichromis fasciatus and Hepsetus odoe) were collected and analyzed for heavy metals. Data obtained were subjected to analysis of variance (ANOVA) test at $0.05 \%$. The results showed higher levels of $\mathrm{Zn}(13.08 \pm 0.45 \mathrm{mg} / \mathrm{g})$ and $\mathrm{Fe}(2.10 \pm 0.56$ $\mathrm{mg} / \mathrm{g}$ ) in fish in comparison with other heavy metals examined. Chromium has exceeded the toxicity threshold in the muscle of the fishes in line with W.H.O standards in food. Cadmium was not detected in soil, while other elements detected were in trace amount below the Environmental Protection Agency allowable limits in soil. In water, except for $\mathrm{Fe}(1.25 \pm 0.02) \mathrm{mg} / \mathrm{l}$, other metals were below allowable limit in water with reference to the World Health Organization's recommendation. This finding indicates that the water is safe for both aquatic life and man.
\end{abstract}

Keywords: Heavy metals; Fishes; Sediment; Reservoir; Ado Ekiti

\section{Introduction}

Aquatic ecosystem is the ultimate recipient of almost everything including heavy metals. This has long been recognized as a serious pollution problem [1]. There are various sources of heavy metals in this ecosystem such as anthropogenic activities like draining of sewage, dumping of domestic wastes and recreational activities. It may also occur in small amounts naturally through the leaching of rocks, airborne dust, forest fires and vegetation [2].

Fish is considered as one of the most significant indicators of metal pollution in aquatic environment [3]. Fish may absorb dissolved elements and heavy metals from surrounding water and food. When fish are exposed to heavy metals in an aquatic ecosystem, they tend to take these metals up which may accumulate in various tissues in significant amounts and are eliciting toxicological effects at critical targets [4]. Some edible species of fish have been widely investigated for those hazardous effects of heavy metals on human health [5].

Sediments are important sinks for heavy metals in aquatic ecosystem. These metals are non-biodegradable and once discharged into water bodies, they can either be adsorbed on sediment particles or accumulated in aquatic organisms. Heavy metal pollution may increase the susceptibility of aquatic animals to various diseases by interfering with the normal functioning of their immune, reproductive and developmental processes [6].

Heavy metals could be found in water at the trace levels. Nonetheless, these constituents are very toxic and tend to accumulate in a long period of time. Heavy metals such as $\mathrm{Pb}, \mathrm{Cd}$ and $\mathrm{Cr}$ are micro-pollutants and of special interest as they have both health and environmental significance due to their persistence, high toxic and bio-accumulation characteristics in water [7]. Heavy metals in human body can affect his health, hence the need to know the concentration of heavy metals in water, sediment and selected fishes in ureje reservoir because of its daily usage by man and proximity to urban pollution.

\section{Materials and Methods}

\section{Study area}

Ureje reservoir is one of the major Dams in Ekiti State. It is located in Ado Ekiti, the State capital. The reservoir overflows across Ado
Ekiti/Ikere road, also cut across the southwest region of the State. The reservoir is strategic to the people of Ekiti State especially the residents of Ado Ekiti. It is the major source of pipe borne water and irrigation (Figure 1).

\section{Collection of fish, water and sediment samples}

Two different species of fish namely: Hemichromis fasciatus and Hepsetus odoe that are commonly seen in the reservoir were collected at two different locations along the stretch of the dam. The fish samples were put into a pre-cleaned polythene bag and placed inside oven for drying in readiness for digestion process. The water sample collected at two different points were also placed in pre-cleaned container and preserved by adding $5 \mathrm{ml}$ of nitric acid $\left(\mathrm{HNO}_{3}\right)$ to it thus, preventing microbial growth in the water sample. The sediment samples were collected from two different point and stored in a pre-cleaned polythene bag and later spread on a flat tray inside the laboratory to be air dried for three days at room temperature $\left(25^{\circ} \mathrm{C}\right)$ after which it was been grinded and sieved for further digestion process.

\section{Digestion of fish samples}

The fish samples were wash with distilled water and dried for 24 hours to constant weight in an oven at $105^{\circ} \mathrm{C}$. After drying the fish sample in the oven, the bones and scales of the dried fish samples were removed and remaining only the muscle, head, tail, eyes, gills of the fish sample. The remaining parts of the fish sample were milled with a mortar and pestle. They were put in a dry labeled crucible and stored until digestion. This involves digesting $2 \mathrm{~g}$ of the grounded samples with $5 \mathrm{ml}$ of $\mathrm{HNO}_{3}$ and $2 \mathrm{ml}$ of $\mathrm{HCLO}_{4}$ and was heated on a hot plate for 30 minutes at $85^{\circ} \mathrm{C}$.

*Corresponding author: Adebayo IA, Faculty of Agricultural Sciences, Ekiti State University, Ado Ekiti, Ekiti State, Nigeria, Tel: 08037252776; E-mail: isreal.adebayo@eksu.edu.ng

Received June 14, 2017; Accepted June 25, 2017; Published June 30, 2017

Citation: Adebayo IA (2017) Determination of Heavy Metals in Water, Fish and Sediment from Ureje Water Reservoir. J Environ Anal Toxicol 7: 486. doi: 10.4172/2161-0525.1000486

Copyright: () 2017 Adebayo IA. This is an open-access article distributed under the terms of the Creative Commons Attribution License, which permits unrestricted use, distribution, and reproduction in any medium, provided the original author and source are credited. 


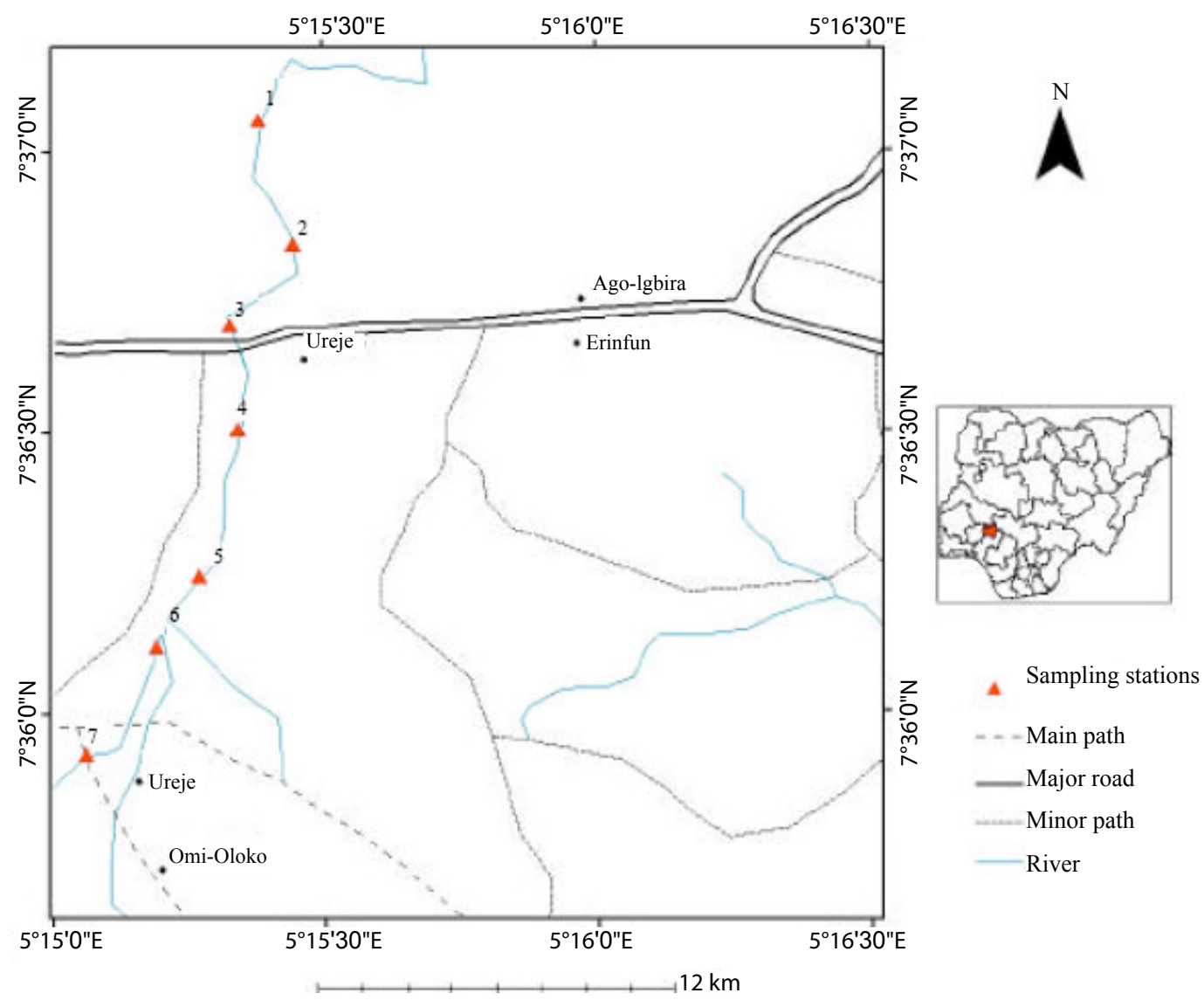

Figure 1: Map of Ureje Dam.

After completing the digestion, the residue were allowed to cool and filtered into a $50 \mathrm{ml}$ volumetric flask. Distilled water was added to it to fill up to the mark. The filtrate was transferred into a pre-cleaned sample bottle and stored under cool temperature until it is taken for further Atomic Adsorption Spectrophotometer (AAS) analysis.

\section{Digestion of water samples}

$100 \mathrm{ml}$ of the water sample was measured with a measuring cylinder and $5 \mathrm{ml}$ of concentrated hydrochloric acid was added to it. The solution was then transferred into a conical flask and heated on the hot plate for two hours at $105^{\circ} \mathrm{C}$ to $25 \mathrm{ml}$. it was then transferred into $100 \mathrm{ml}$ volumetric flask and distill water was added to fill up to the mark where it was filtered and transferred into the pre-cleaned sample bottle and taken for further Atomic Adsorption Spectrophotometer (AAS) analysis.

\section{Digestion of sediment samples}

After air drying the Sediment samples for 3 days and ground into smaller particles, it was sieved and went through digestion process: $2 \mathrm{~g}$ of the sediment sample was weighed and poured into a beaker, $5 \mathrm{ml}$ of hydrogen trioxonitrate $(\mathrm{v})$ acid $\left(\mathrm{HNO}_{3}\right)$ was added together with $2 \mathrm{ml}$ of perchloric acid $\left(\mathrm{HClO}_{4}\right)$ and $5 \mathrm{ml}$ of hydrogen fluoride (HF) was added and heated for 1 hour on a heater at $160^{\circ} \mathrm{C}$. After proper digestion, the sample was allowed to cool down and it was filtered. The filtrate was transferred into $100 \mathrm{ml}$ volumetric flask and made up to mark with distilled water. The prepared sample solution was transferred into the pre-cleaned labeled sample bottles in readiness for Atomic Adsorption Spectrophotometer (AAS) analysis.

\section{Metal determination procedure using AAS}

A black model 200A flame Atomic Absorption Spectrometer was used in the metal analysis of the sample. The major underlined principle of AAS is that the ground state atoms are capable of absorbing radiant energy of their own specific resonance wavelength when passed through a solution containing the atoms in question, then part of the light will be absorbed. The extent of absorption is proportional to the number of ground state atoms present in the flame.

\section{Results and Discussion}

\section{Concentration of heavy metals in fish parts: Hemichromis fasciatus}

Concentration of heavy metals in different parts of Hemichromis fasciatus adult fish from Ureje dam is shown in Table 1 below. Concentrations of Iron $(\mathrm{Fe})$, Copper $(\mathrm{Cu})$, Zinc $(\mathrm{Zn})$, Lead $(\mathrm{Pb})$, Cadmium (Cd), Chromium (Cr) and Manganese (Mn) in the Muscle, head, eye, tail and gills of the fish samples were determined. Although there was no significant difference in metal concentration in each part of the fish for each metal but the results showed higher levels of $\mathrm{Zn}(13.08 \pm$ $0.45 \mathrm{mg} / \mathrm{g})$ and $\mathrm{Fe}(2.10 \pm 0.56)$ in comparison with other heavy metals examined. Cadmium and Copper were not detected in some parts of the fish, indicating their low concentrations in the fish. Several studies have indicated that metal accumulation in fish depends on numerous factors such as food habits of the fish [8], tropic status, source of a particular metal, distance of the fish from the contamination source and 
the presence of other ions in the environment [9]. Also, [10] reported that metal accumulation in the tissues of fish varied according to the rates of uptake, storage and elimination. The high levels of iron and zinc in this study could be attributed to their high demand as essential elements in blood haemoglobin and as a dietary essential trace metals [11]. Chromium has exceeded the toxicity threshold in the muscle of the fish in line with W.H.O standards in food.

\section{Concentration of heavy metals in fish parts: Hepsetus odoe}

The results in Table 2 below show that the metal concentrations in fish organs of hepsetus odoe followed the same pattern with Hemichromis fasciatus except that $\mathrm{Cd}, \mathrm{Cu}$ and $\mathrm{Pb}$ were partially detected in the fish. Also, $\mathrm{Fe}(3.09 \pm 1.09)$ and $\mathrm{Cr}(0.15 \pm 0.03)$ were at the toxicity threshold in the muscle of the fish in line with W.H.O standards in food. This may be attributed to the abundance of these metals in the ecosystem and the tropic status of the fish [6]. A remarkable relationship between heavy metals concentrations in water and fish were observed by Fernandes et al. [12].

\section{Concentration of heavy metals in sediment samples}

Table 3 below shows the total extractable concentration of heavy metals from sediments in the study area. Cadmium was not detected in the two locations, while $\mathrm{Cr}, \mathrm{Pb}$ and $\mathrm{Fe}$ were significantly $(\mathrm{p}>0.05)$ higher in location A than location $\mathrm{B}$. The results obtained showed that the sediment samples were lower in heavy metals concentration in line with reference values for USEPA [6].

\section{Heavy metal concentrations in water sample}

Heavy Metal concentrations in water samples from Ureje dam is presented in Table 4. Lead $(\mathrm{Pb})$ was not detected in both stations. Zinc was in trace levels (0.02-0.06). Except for Fe, the heavy metal load in water was far below toxicity threshold level in comparison with W.H.O allowable limits in water [7].

\section{Conclusion and Recommendations}

This study examined the concentrations of Iron $(\mathrm{Fe})$, Copper $(\mathrm{Cu})$, Zinc ( $\mathrm{Zn})$, Lead $(\mathrm{Pb})$, Cadmium $(\mathrm{Cd})$, Chromium $(\mathrm{Cr})$ and Manganese $(\mathrm{Mn})$ in the Muscle, head, eye, tail and gills of the fish samples from Ureje Dam and compared the results with the World Health Organization (W.H.O) allowable limits in food. Also, the same elements were determined in water and sediment in line with US EPA, 2010. The observed differences in metal concentrations in the two species of fish examined indicated difference in metal uptake as reported by Oguzie [13]. Metal uptake and accumulation has a direct link with the feeding habit of fish and where fish resides in water [14]. The reason for higher metal uptake in Hepsetus odoe compared to Hemichromis faciatus is that Hepsetus odoe is carnivorous and benthic while Hemichromis faciatus is an herbivore and pelagic. It was generally observed that $\mathrm{Zn}$ and Fe were more concentrated in the head and muscle than other parts of the fish, although there was a lack of general pattern of uptake and elimination which is species dependent as reported by Tuzen [8].

The concentration of heavy metals in water and sediments in the present study showed trace amount of heavy metals, mainly from anthropogenic input from the city of Ado Ekiti. The level of metal accumulation in fish, water and sediment in the study area has not constitutes health hazards to aquatic life or man. But it is necessary to monitor the usage of the dam by appropriate agencies by adhering strictly to the rules guiding its safety. Government must ensure safe disposal of agricultural, domestic sewage and industrial effluents and recycled where possible to avoid these metals and other contaminants from going into the dam. It is hereby recommended that, location of automobile workshops, dumping of domestic sewage and other activities that are inimical to the safe use of the dam should be discouraged, while regular assessment of the dam to see to its cleanness and proper maintenance should be encouraged.

\begin{tabular}{|c|c|c|c|c|c|c|c|}
\hline Sample & $\mathbf{C d}$ & $\mathbf{C r}$ & $\mathbf{Z n}$ & $\mathbf{C u}$ & $\mathbf{P b}$ & $\mathbf{F e}$ & $\mathbf{M n}$ \\
\hline Head & $0.01 \pm 0.00$ & $0.08 \pm 0.02$ & $13.08 \pm 0.45$ & ND & $0.30 \pm 0.04$ & $2.30 \pm 0.56$ & $0.10 \pm 0.01$ \\
\hline Muscles & $0.01 \pm 0.00$ & $0.20 \pm 0.05$ & $11.65 \pm 0.40$ & $0.03 \pm 0.00$ & $0.10 \pm 0.05$ & $1.90 \pm 0.45$ & ND \\
\hline Eye & ND & $0.14 \pm 0.05$ & $12.19 \pm 0.42$ & ND & $0.10 \pm 0.05$ & $0.90 \pm 0.50$ & ND \\
\hline Tail & $0.07 \pm 0.02$ & $0.11 \pm 0.03$ & $12.22 \pm 0.40$ & ND & $0.10 \pm 0.03$ & $1.08 \pm 0.46$ & $0.13 \pm 0.02$ \\
\hline Gills & $0.01 \pm 0.00$ & $0.12 \pm 0.02$ & $12.78 \pm 0.41$ & ND & $0.10 \pm 0.05$ & $2.10 \pm 0.44$ & $0.13 \pm 0.01$ \\
\hline W.H.O & 2.00 & 0.050 .15 & $10-75$ & $1-3$ & $0.1-0.2$ & $1-3$ & - \\
\hline
\end{tabular}

Table 1: Heavy Metals concentrations (mg/g) in Fish Parts (Hemichromis fasciatus) with the W.H.O Allowable Limits in food.

\begin{tabular}{|c|c|c|c|c|c|c|c|}
\hline Sample & Cd & Cr & Zn & Cu & Pb & Fe & Mn \\
\hline Head & $0.01 \pm 0.03$ & ND & $10.13 \pm 2.72$ & $0.04 \pm 0.01$ & $0.20 \pm 0.05$ & $2.85 \pm 1.07$ & $0.11 \pm 0.02$ \\
\hline Muscle & ND & $0.16 \pm 0.03$ & $11.52 \pm 2.45$ & ND & $0.10 \pm 0.03$ & $3.09 \pm 1.09$ & $0.31 \pm 0.08$ \\
\hline Eye & ND & $0.08 \pm 0.03$ & $10.02 \pm 1.79$ & ND & ND & $1.20 \pm 0.08$ & $0.12 \pm 0.02$ \\
\hline Tail & ND & $0.05 \pm 0.03$ & $10.02 \pm 2.67$ & $0.03 \pm 0.01$ & ND & $1.78 \pm 0.09$ & $0.20 \pm 0.02$ \\
\hline Gills & ND & $0.09 \pm 0.03$ & $11.79 \pm 1.70$ & ND & $0.10 \pm 0.02$ & $0.10 \pm 0.05$ & $0.11 \pm 0.01$ \\
\hline W.H.O & 2.00 & $0.05-0.15$ & $10-75$ & $1-3$ & $0.1-0.2$ & $1-3$ & - \\
\hline
\end{tabular}

ND: Not Detected

Table 2: Heavy Metals Concentrations (mg/g) in Fish Parts (Hepsetus odoe) with the W.H.O Allowable Limits in food.

\begin{tabular}{|c|c|c|c|c|c|c|c|}
\hline Sample & Cd & Cr & Zn & $\mathbf{C u}$ & $\mathbf{P b}$ & $\mathbf{F e}$ & $\mathbf{M n}$ \\
\hline Location A (mg/kg) & ND & $32.46 \pm 0.19^{\mathrm{a}}$ & $200.59 \pm 0.90$ & $100.40 \pm 0.16$ & $20.80 \pm 1.10^{\mathrm{a}}$ & $13.01 \pm 0.65^{\mathrm{a}}$ & $1.20 \pm 0.60^{\mathrm{b}}$ \\
\hline Location B (mg/kg) & ND & $10.28 \pm 0.12^{\mathrm{b}}$ & $200.67 \pm 0.97$ & $100.36 \pm 0.14$ & $10.40 \pm 1.10^{\mathrm{b}}$ & $10.10 \pm 0.76^{\mathrm{b}}$ & $2.50 \pm 0.65^{\mathrm{a}}$ \\
\hline USEPA allowable limits mg/kg & & 3,000 & 7,500 & 4,300 & 420 & - & 230 \\
\hline
\end{tabular}

$\mathrm{ND}=$ Not detected

Table 3: Concentration of Heavy Metals in Sediment Samples. 
Citation: Adebayo IA (2017) Determination of Heavy Metals in Water, Fish and Sediment from Ureje Water Reservoir. J Environ Anal Toxicol 7: 486. doi: 10.4172/2161-0525.1000486

Page 4 of 4

\begin{tabular}{|c|c|c|c|c|c|c|c|}
\hline Sample & Cd & Cr & Zn & Cu & Pb & Fe & Mn \\
\hline Station A (mg/l) & ND & ND & $0.06 \pm 0.10$ & $0.03 \pm 0.01$ & ND & $1.25 \pm 0.02$ & $0.10 \pm 0.03$ \\
\hline Station B $(\mathrm{mg} / \mathrm{l})$ & $0.03 \pm 0.01$ & $0.02 \pm 0.01$ & $0.02 \pm 0.00$ & ND & ND & $1.10 \pm 0.01$ & $0.02 \pm 0.01$ \\
\hline W.H.O. $(\mathrm{mg} / \mathrm{l})$ & 2.00 & $0.05-0.15$ & $10-75$ & $1-3$ & $0.1-0.2$ & $1-3$ \\
\hline
\end{tabular}

ND: Not detected

Table 4: Concentration of Heavy Metals in Water Sample in comparison with W.H.O Water Quality Guidelines.

\section{References}

1. Farombi EO, Adelowo OA, Ajimoko YR (2007) Biomarkers of oxidative stress and heavy metal levels as indicator of environmental pollution in African Catfish (Clarias gariepinus) from Nigeria Ogun River. International Journal of Environmental Research and Public Health 4: 158-165.

2. Özmen H, Külahçı F, Çukurovalı A, Doğru M (2004) Concentrations of heavy metal and radioactivity in surface water and sediment of Hazar lake (Elazıg, Turkey). Chemosphere 55: 401-408.

3. Rashed MN (2001) Monitoring of environmental heavy metals in fish from Nasser Lake. Environ Int 27: 27-33.

4. Seymore T (1994) Bioaccumulation of metals in Barbus marequensis from the Olifants River, Kruger National Park, and lethal levels of $\mathrm{Mn}$ to juvenile Oreochromis mossambicus. MSc Thesis, Rand Afrikaans University, South Africa.

5. Begum A, Amin MN, Kaneco S, Ohta K (2005) Selectedelemental composition of the muscle tissue of three species of fish, Tilapia nilotica, Cirrhina mrigala and Clarius batrachus, from the fresh water Dhanmondi Lake in Bangladesh. Food Chemistry 93: 439-443.

6. US Environmental Protection Agency (EPA) (2010) Guidance on Evaluating Sediment Contaminant Results. Division of Surface Water, Standards and Technical Support Section.
7. WHO (2008) Guidelines for drinking water quality. World Health Organization, Geneva.

8. Tuzen M (2003) Determination of heavy metals in fish samples of the Mid Dam Lake Black Sea (Turkey) by graphite furnace atomic absorption spectrometry. Food Chemistry 31: 119-123.

9. Deb SC, Fukushima T (1999) Metals in aquatic ecosystems. Mechanisms for uptake, accumulation and release. Int. Environ. Stud 56: 385-393.

10. Kalay M, Canli M (2000) Elimination of Essential (Cu, Zn) and Non-Essential $(\mathrm{Cd}, \mathrm{Pb})$ Metals from Tissues of a Freshwater Fish Tilapia zilli. Turk J Zool 24 429-436.

11. Kambole MS (2002) Managing the water quality of the Kafue River. In: Water demand management for sustainable development. 3rd Water Net Werfsa Symposium, Dares Salaam, pp: 1-6.

12. Fernandes C, Fontaínhas-Fernandes A, Cabral D, Salgado MA (2008) Heavy metals in water, sediment and tissues of Liza saliens from Esmoriz-Paramos lagoon, Portugal. Environ Monit Assess 136: 267-275.

13. Oguzie FA (2003) Heavy metals in fish, water and effluents of lower, Ikpoba River in Benin City, Nigeria. Pak Journ Sci Ind Res 46: 156-160.

14. Shrivastava P, Saxena A, Swarup A (2001) Heavy metal pollution in sewage fed Lake of Bhopal, (M.P.) India. Lake Reservoir Research Management 8: 1-4. 